Revista de Literatura, História e Memória

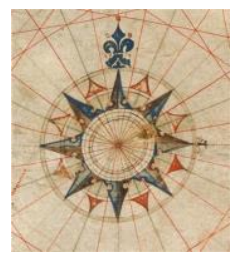

Seção: Pesquisa em Letras no contexto Latino-americano e Literatura, Ensino e Cultura

ISSN 1983-1498

VOL. 17 - Nº 29 - 2021

U N I O E S T E / CA S C A V E L - p. 08-26

\title{
O PACTO AMBÍGUO DA AUTOFICÇÃO COMO ATO INTENCIONAL E DURATIVO
}

\author{
The ambiguous pact of autofiction as intentional and \\ durative act
}

\section{Edson Ribeiro Silva ${ }^{1}$}

RESUMO: O presente estudo focaliza o conceito de pacto de leitura, ou contrato, em sua aplicação à autoficção. O pacto ambíguo, de Alberca, que agrupa de modo eficiente as noções de pacto autobiográfico e romanesco, de Lejeune, quando atreladas a uma mesma modalidade de narrativa, pode ser visto a partir do pacto que o autor faz com seu leitor-ideal, conforme Iser. Tais concepções de pacto encontram um respaldo linguístico nas noções de ficção de Searle, que enxerga nela uma suspensão de convenções do discurso que tenciona ser apreendida como narrativa do real. Percebe-se, no entanto, que as concepções de pacto de leitura ora atentam para a configuração da obra como gênero e fazem com que aquele repouse sobre o paratexto, ora atentam para o conteúdo dela e fazem com que ele ocorra no decorrer da leitura. Conclui-se, aqui, que o pacto ambíguo necessita do paratexto, do gênero, para ser estabelecido como ficção, mas a natureza autobiográfica só pode ser percebida através da duração da leitura, ou seja, os dois planos de leitura fixados por Iser constituem uma forma mais segura de compreensão desse pacto, que é forma convencionada de jogo.

PALAVRAS-CHAVE: Autoficção; Pacto de leitura; Ficção; Intencionalidade.

ABSTRACT: The present study focuses on the concept of reading pact, or contract, in its application to autofiction. Alberca's ambiguous pact, which efficiently groups Lejeune's notions of autobiographical and novelistic pact, when linked to the same narrative modality, can be seen from the pact that the author makes with his ideal reader, such as Iser thinks it. These conceptions of pact find linguistic support in Searle's notions of fiction, who sees in it a suspension of discourse conventions that intends to be perceived as narrative of reality. It is noticed, however, that the concepts of reading pact sometimes pay attention to the configuration of the work as a genre and make it rest on the paratext, sometimes pay attention to its content and cause it to occur during the reading. It is concluded, here, that the ambiguous pact needs the paratext, as genre, to be established as fiction, but the autobiographical nature can only be perceived through the reading duration, that is, the two reading plans fixed by Iser constitute a safer way of understanding this pact, which is the agreed form of play.

KEYWORDS: Autofiction; Reading pact; Fiction; Intentionality.

\section{PACTOS DE LEITURA E A MEMÓRIA COMO ELEMENTO CONSTITUTIVO DA NARRATIVA FICCIONAL}

Os estudos sobre autoficção costumam ancorar-se na dicotomia que o próprio conceito sugere. Ser ficção ou ser autobiografia. Ou seja, a dicotomia que aparece nos estudos de

\footnotetext{
${ }^{1}$ Pós-doutor em Letras pela Universidade Estadual de Londrina (UEL). Professor do Programa de Mestrado e de Doutorado em Teoria Literária da Uniandrade, em Curitiba, Paraná.
} 
Philippe Lejeune sobre o pacto autobiográfico. Essa dicotomia, em Lejeune, já aparece devidamente esgarçada através da noção de pacto, que relativiza as naturezas de invenção e de realidade do ficcional e do autobiográfico. A existência de um pacto de leitura faz com que a natureza dos textos seja mais convencional que essencial.

A noção de ficção como invenção é construída a partir desse pacto de leitura. O pacto da ficção é chamado por Lejeune de "romanesco", e se contrapõe ao "pacto autobiográfico" (LEJEUNE, 2014, p. 68s) pela não exigência, pelo leitor, de informações extratextuais que comprovem a verdade do narrado. A autobiografia que se apresenta como tal compromete-se com a possibilidade de se comprovar isso que, ainda em Lejeune, é chamado de "verdade" (LEJEUNE, 2014, p. 66s), conceito que acaba por fazer do romanesco ou do ficcional algo atrelado ao imaginário. Em Lejeune, ainda há resquícios daquela oposição entre a memória que apenas registra a imagem do real, como eikon, e aquela que cria imagens irreais a partir da fantasia, que aparece no Teeteto, de Platão. Hoje, essas possibilidades da memória costumam ser vistas mais como resultado da intenção de quem rememora do que como diferenças essenciais na natureza da coisa rememorada.

Os desdobramentos dos estudos sobre autoficção têm problematizado essa oposição entre real e invenção. A natureza de coisa real da autobiografia seria ilusória. A natureza de invenção da narrativa ficcional também. Teóricos da memória e da narrativa amparam essa problematização. A noção de "eu desfigurado", de Paul de Man (1994), faz com que a memória seja a resultante de um esforço pela reconstituição do passado através da elaboração de imagens. Dela não escaparia nem a ficção nem a autobiografia. As três mímesis categorizadas por Paul Ricoeur (1994) para a narrativa voltam-se para a análise do percurso criador que dá origem a ela: assim, existem a prefiguração, momento em que as imagens contidas na memória servem como ancoragem para a criação; a configuração corresponde ao momento da elaboração discursiva daquilo que a memória selecionou; a refiguração, que ocorre quando o leitor apreende a obra já configurada a partir de sua memória pessoal, de seu referencial de imagens do real. Ou seja, em Ricoeur a memória, tanto do autor quanto do leitor, é elemento que torna possível a representação da realidade na narrativa, assim como sua compreensão. O teor desse referencial não destitui a narrativa de sua intenção de representação do real.

Inúmeras teorias tratam essa problematização como ilusória. Por outro lado, também não percebem que as visões que absolutizam a natureza da memória se estendem a toda forma de narrativa, a toda tentativa de representação do real pela linguagem, e não apenas a 
modalidades que se autodefinem como verdade ou como criação, casos da autobiografia e da ficção.

Essa dicotomia é incorporada ao modo pelo qual a autoficção constitui seu pacto de leitura. Desde Doubrovsky (2014) e sua conceituação da autoficção como narrativa em que a natureza do pacto de leitura permanece indefinida entre o autobiográfico e o romanesco, várias maneiras de se conceituar essa indefinição foram criadas. Esse pacto foi oximórico, anfíbio, instável, entre outras definições. Mas a de "pacto ambíguo", de Manuel Alberca (2007), costuma ser vista como síntese daquilo que aparecia em Doubrovsky e nos teóricos que assumiram a sua visão acerca do pacto autoficcional, além de ter suplantado a identidade onomástica de autor-narrador-protagonista como elemento que identifica essa modalidade.

É preciso que se reconheça em todas essas categorias de pacto de leitura algo que se atrela a modos de as disciplinas da Linguística e da Teoria Literária que se ocupam da recepção dos textos focalizarem como o reconhecimento da natureza deles determina o modo como eles são recebidos. Teorias como a dos elementos da textualidade, elaborada pela Linguística Textual, já focalizavam esse modo de a natureza de um texto ser percebida antes de sua leitura como uma possibilidade de a intenção que presidiu sua elaboração ficar evidente para o receptor. A decisão de ler ou não pode ser tomada nesse reconhecimento do gênero. Na visão de Wolfgang Iser (1996), a recepção do texto literário ocorre como o reconhecimento de regras de um jogo instaurado. A assimilação dessas regras e a decisão de aceitá-las como determinantes da recepção são uma forma de contrato de leitura. Iser defende que cada obra é um jogo com regras específicas. Essas regras correspondem a modos de cada obra acatar, reelaborar ou transgredir aquelas especificidades do gênero literário a partir do qual o leitor a reconhece. $\mathrm{O}$ autor dispõe de meios para fazer com que a leitura oscile entre o reconhecimento do gênero como forma cristalizada na tradição literária e o dos modos através dos quais cada obra específica a tratou, criando regras únicas de jogo. Há um reconhecimento que precede a leitura e outro que ocorre enquanto esta acontece.

Ideias como as da Linguística Textual ou as do ato de leitura iseriano pressupõem o reconhecimento do gênero como princípio norteador tanto dos sentidos quando da realização estética pretendida. Através da forma cristalizada, convencionada, pela qual um gênero tornase reconhecível até mesmo antes da leitura (entendida naquela modalidade em que é a apreensão de cada signo), torna-se possível atribuir, de imediato, uma intenção ao texto. Essa camada mais externa, tantas vezes ostentada como paratexto, no caso da narrativa, introduz um modo de leitura que, sem dúvida, começa pelo reconhecimento de uma intenção, que vai 
do mais generalizado ao mais particularizado, ou seja, da forma cristalizada ao modo como o autor construiu uma obra específica a partir dela.

A ideia de pacto de leitura atrela-se, inevitavelmente, à de que existe uma intenção que preside a elaboração do texto. No caso da obra literária, além daquilo que a define como arte, ou seja, a opacidade da linguagem, conforme Lefebve (1980), ou o que Ricoeur (1994, p. 118) chama de "configuração", existe a prevalência do gênero sedimentado sobre suas possibilidades de inovação: "É ainda o ato de ler que acompanha o jogo entre a inovação e a sedimentação dos paradigmas que esquematizam a tessitura da intriga”. A mesma relação é a que estabelece, para Iser (1996), os dois planos do ato de leitura: reconhecer o gênero sedimentado para, em seguida, reconhecerem-se as especificidades que o autor configurou para a obra em particular. O percurso da leitura constitui-se no reconhecimento de uma dialética que principia no fixação de uma intencionalidade. Assim:

Quando dois segmentos textuais são interligados, eles não serão simultaneamente focalizados pelo leitor. Isso já se mostra no fato de que os segmentos textuais, situados em diferentes perspectivas, aparecem de forma sucessiva no fluxo da leitura. O ponto de vista do leitor salta portanto de um segmento para outro. O que ele enfoca torna-se tema para ele. Se uma posição é tematizada, a outra não pode ser tema também. (ISER, 1996, p. 149).

Após falar extensamente sobre repertório e sobre o reconhecimento, pelo leitor, de como a tradição literária configura o gênero lido, Iser passa a falar de tema como momentos de reconhecimento dentro da duração da leitura. Nessa atenção para o tema certamente ocorre o reconhecimento da natureza autobiográfica dentro do texto ficcional.

A autoficção não pode ser definida como gênero literário. Sua natureza é a mesma da escrita-de-si ou da ficção, ou seja, uma condição existenciária que faz com que ela possa ser utilizada em gêneros diversos, como o romance, a novela, o conto e a crônica. Tais gêneros estão sedimentados, na tradição literária, como constituídos por narrativas ficcionais, produzidas pelo imaginário. Assim, eles não se esquivam dessa natureza. $\mathrm{O}$ elemento que pode ser focalizado como inovação também diz respeito a outra natureza: ser autobiografia, não mais como gênero textual, mas como escrita-de-si, texto que trata do próprio eu do autor. Aqui, é preciso que se atente para o mesmo percurso evolutivo que fez com que Lejeune, em princípio, reconhecesse a autobiografia como um gênero para, anos depois, considerar as inúmeras possibilidades de escrita sobre o eu como autobiográficas, fazendo do conceito uma nova condição existenciária de textos pertencentes a gêneros diversos, que podem ou não ser narrativos, assim como podem ou não ser ficcionais. 
Mas Lejeune enxergava o entrecruzamento da autobiografia e da ficção, na narrativa literária, naquilo que definiu como "ficção autobiográfica", ou seja, o narrado tem origem na memória, mais especificamente como fato ocorrido com o autor. Os laços que unem autobiografia, como memória, e ficção, como elaboração de gêneros convencionados como tal, são tênues. O pacto da ficção autobiográfica é "fantasmático" (LEJEUNE, 2014, p. 66s), pode permanecer impreciso. Mas é uma imprecisão que não assume aquela condição de pacto essencial à apreensão, como foi proposto por Doubrovsky e Alberca. Quase como se aquela prefiguração, de que fala Ricoeur, não precisasse ser evidenciada no pacto de leitura. Ela pode ser reconhecida pelo leitor-ideal, mas pode passar despercebida do leitor comum. O entrecruzamento proposto por Doubrovsky faz com que as duas naturezas se misturem de modo que a ambiguidade do texto já esteja prevista como pacto de leitura. A intencionalidade da autoficção precisa de uma ambiguidade pactual que possa ser detectada, de imediato, como gênero ficcional, através do paratexto, mas que se desvela como autobiografia, no sentido mais abrangente de Lejeune, conforme a apreensão do texto ocorre. Em Doubrovsky, ela é detectada através da identidade onomástica, pista para que o leitor procure ou reconheça biografemas. Em teóricos posteriores, esse reconhecimento vai ganhando modos diversos de confirmação, como a atitude performática, de que fala Diana Klinger (2012), sempre ações que comprovam que o elemento autobiográfico é depreendido na duração da leitura, enquanto o ficcional é percebido através do repertório do leitor ao instaurá-la.

\section{A INTENCIONALIDADE E OS CONTRATOS DE LEITURA}

Antoine Compagnon (1999, p. 96) chama de "presunção de intencionalidade" o estabelecimento do reconhecimento das intenções do autor como necessário à depreensão dos sentidos do texto. O posicionamento de Compagnon é mais uma decorrência de sua própria intenção ao produzir $O$ demônio da teoria: percorrer os conceitos basilares da Teoria Literária para negá-los, ver neles construtos sem aplicabilidade empírica. No entanto, falta ao teórico exatamente uma ancoragem teórica capaz de fazer crer que tais conceitos sejam falaciosos. Tautologia da qual não se foge. Ao querer negar à teoria, sobretudo à literária, uma aplicabilidade, dada a diversidade de possibilidades da literatura, Compagnon reduz teoria ao senso-comum: elucubrações que não abarcam todo seu objeto de estudo. No entanto, é o próprio Compagnon quem persegue, na teoria, essa natureza essencialista, que a teoria sobre literatura não tenciona para si, como analista de fenômenos díspares. É por existirem disparidades que se detectam intenções diversas dentro desse objeto de estudo. 
Ao querer fazer crer que nenhum texto possa ser apreendido a partir daquilo que seu autor tencionava, mas apenas da experiência individual do leitor, Compagnon esbarra na sua própria aporia: a impossibilidade de escrever uma obra teórica que resulte em convencimento de seus pressupostos através apenas de suposições de como a leitura se dá. A intencionalidade, evidentemente, é pressuposto e não presunção. O próprio fato de ele comentar conceitos milenares, como os de mímesis e verossimilhança, mostra que existe uma coincidência nos modos pelos quais aqueles têm sido apreendidos. Não poderia haver sensocomum a partir de conceitos expostos em obras teóricas se a recepção dependesse estritamente da experiência do leitor, sem que o autor pudesse direcionar a leitura a partir de intenções abrangentes. A não ancoragem em teorias leva o autor a tautologias, como a de dizer que "literatura é literatura" (COMPAGNON, 1999, p. 44s), recurso que demonstra apenas tentativa de evadir-se da criação de uma argumentação que não fizesse uso dos conceitos recorrentes da Teoria Literária.

Essa negação de Compagnon encontra um de seus principais contrapontos na obras do linguista John R. Searle. Teórico da corrente denominada atos de fala, Searle enxerga em cada ação ilocutória uma função prévia. Desempenhar uma ação comunicativa é possível porque os atos de fala são produzidos e apreendidos a partir de uma função. Quem se comunica escolhe a ação ilocutória que corresponde à sua intenção. Tal qual ocorre com os gêneros textuais, a ação ilocutória é percebida como estando a serviço de uma finalidade tencionada pelo locutor. $\mathrm{O}$ ato de advertir existe porque o locutor tencionou produzir uma advertência. No entanto, Searle torna essa relação entre intenção e realização mais complexa quando se trata de texto escrito, de gêneros mais extensos, pois estes contêm inúmeros atos ilocutórios, de natureza diversa. A redução do texto a um ato é problemático. Por isso, a realização da obra de arte literária enquadra-se na categoria dos atos de fala perlocucionários (SEARLE, 2002a, p. 223s), em que a emissão constitui o ato representado pela fala. Ou seja, criar uma obra de arte literária, como um romance, é possível enquanto se cria, pela linguagem, essa obra tencionada. Atos ilocutórios comuns, como pedir, ordenar, podem estar inseridos na obra, mas o ato perlocucionário de criar uma obra literária só ocorre porque há convenções sociais e linguísticas que fazem com que esse ato crie a obra pretendida e não o ato ilocutório trivial. Aquele que diz estar fazendo um romance pode ser comparado ao juiz que declara o réu culpado e este passa a sê-lo a partir desse ato de fala. Uma obra de arte literária fica sendo porque o ato de fala que a produz segue um conjunto de convenções que tornam essa ação reconhecível. Assim, Searle não destoa daqueles teóricos que veem na literatura a literatura: havia uma intenção de que a emissão produzida fosse recebida como tal. 
Essa condição primordial altera, sem dúvida, o modo de recepção de todos os atos ilocutórios presentes na obra literária. Afinal, a intenção que se detecta em todo ato ilocutório é reconhecida no texto literário, mas o efeito esperado não é o de situações em que agentes de fala reais comunicam. Está-se no âmbito da representação. $O$ ato ilocutório daquele que fala como agente da representação é distinto daquele do agente representado. E essa diferença repousa sobre uma intenção: "Representar exige um agente representador e um ato intencional de representação e, portanto, a representação exige a Intencionalidade e não pode ser usada para explicá-la” (SEARLE, 2002a, p. 19).

A necessidade de um agente representador expor sua intencionalidade na obra literária, como contrato de leitura, é também a ação que produz a natureza ficcional do texto. Searle se inscreve entre os teóricos que não reconhecem elementos linguísticos específicos que tornem um texto ficcional:

Ora, fingir é um verbo intencional: ou seja, é um daqueles verbos que integram em si o conceito de intenção. Não se pode realmente dizer que se fingiu fazer algo a menos que houvesse a intenção de fingir fazê-lo. Portanto, a nossa primeira conclusão leva-nos imediatamente à segunda conclusão: o critério identificador a respeito de um texto ser ou não uma obra de ficção tem necessariamente de residir nas intenções ilocutórias do autor. Não há propriedade textual, sintáctica ou semântica, que identifique um texto como obra de ficção. O que o faz ser uma obra de ficção é, por assim dizer, a postura ilocutória que o autor assume relativamente ao texto, e essa postura depende das intenções ilocutórias complexas que o autor tem quando escreve ou de algum modo compõe o texto. (SEARLE, 2002b, p. 96).

O fingimento que gera a enunciação de texto ficcional depende de uma postura ilocutória e não da alteração das propriedades linguísticas do texto. O fato de Searle não reconhecer propriedades textuais que façam de um texto uma obra de ficção faz com que essa condição dependa de uma relação contratual, ou seja, uma forma de pacto de leitura.

Searle recorre ao que chama de "convenções" para explicar como uma postura ilocutória pode ser produzida e apreendida como é tencionada. Sua nomenclatura é recorrentemente binária, mesmo quando fala de "intenções ilocutórias complexas", que se aplicam tanto à literatura em geral quanto ao texto ficcional. Esse binarismo obriga o autor a separar aquilo que, no texto literário, se confunde. Um exemplo ocorre quando ele separa discurso ficcional e discurso sério, ou ficção e asserção. Mesmo após dizer que o texto ficcional é composto pelos mesmos mecanismos linguísticos que compõem as asserções, ou atos ilocutórios que pretendem ser entendidos como expressão do real sem o fingimento, ele diz que obras ficcionais podem conter esses atos assertivos, separando-os do que considera 
como ficcional:

Por vezes, o autor de uma história ficcional inserirá na história locuções que não são ficcionais e não fazem parte da história. Para tomar um exemplo célebre, Tolstoi começa Anna Karenina com a frase "As famílias felizes são todas felizes do mesmo modo, as famílias infelizes são infelizes de diferentes modos". Essa, em meu entender, não é uma frase ficcional, é séria. É uma asserção genuína. Faz parte do romance mas não parte da história ficcional. (SEARLE, 2002b, p. 100).

Trata-se, sem dúvida, de uma visão redutora e ingênua, pois atrela a voz do narrador à do autor e à sua personalidade. Uma visão que se reduz ao foco narrativo comumente chamado de narrador onisciente intruso, e que retira o enunciado assertivo do resultado final do texto como gênero literário convencionado como ficcional. A postura ficcional acabaria restrita ao enredo e não à fabulação como um todo orgânico e coerente. Asserções genuínas estariam opostas às asserções fingidas; o ficcional, ao sério. O binarismo de Searle torna-se um problema para a natureza da ficção autobiográfica ou da autoficção. Mas o fato de considerar-se o entendimento da natureza do texto como resultante de uma relação contratual pode libertá-lo dessa limitação, ainda que Searle não o preveja. Afinal, a justaposição de elementos fingidos e sérios ocorre, ou as ideias de Paul Ricoeur e de Paul de Man sobre a natureza da memória na narrativa não fariam sentido. Dessa forma, ele se aproxima mais da ideia de tema de Iser, que faz do texto uma sequência de elementos observados em separado.

Searle faz com que tanto o reconhecimento do que seja literatura quanto o do que seja ficção estejam ancorados em convenções. Mas coloca a responsabilidade sobre as decisões ora sobre um, ora sobre outro, o que acaba por quebrar essas relações contratuais:

Segundo, creio (embora não procure demonstrá-lo aqui) que "literatura" é o nome de um conjunto de atitudes que tomamos para com um segmento de discurso, não o nome de uma propriedade interna do segmento de discurso, embora a razão por que tomamos as atitudes que tomamos seja evidentemente, pelo menos em parte, uma função das propriedades do discurso e não inteiramente arbitrária. Grosso modo, cabe aos leitores decidir se uma obra é literatura ou não, cabe ao autor decidir se essa obra é ficção. (SEARLE, 2002b, p. 97. Grifos do autor).

Evidentemente, a decisão sobre produzir ou não arte é essencial para que exista a opacidade da linguagem, que diferencia a configuração de recursos em cada uma das artes daquelas ações, como escrever, pintar, filmar, quando feitas sem tal intenção. A opacidade da linguagem literária é condição para que ela seja reconhecida como arte, mesmo quando 
composta por asserções genuínas. Searle coloca no autor a responsabilidade sobre definir a natureza ficcional da obra. Mas é preciso que se entenda que essa intenção somente se efetiva quando o leitor reconhece as asserções dela como fingidas, algo que, para o linguista, não depende de sua constituição linguística. Searle estabelece, para as asserções genuínas ou sérias, um conjunto de convenções, que chama de "verticais":

1. A regra essencial: o autor de uma asserção compromete-se com a verdade da proposição expressa.

2. As regras preparatórias: quem fala tem de estar em condições de apresentar indícios ou razões a favor da verdade da proposição expressa.

3. A proposição expressa não pode ser obviamente verdadeira tanto para quem fala como para o ouvinte no contexto da locução.

4. A regra da sinceridade: quem fala compromete-se com a crença na verdade da proposição expressa. (SEARLE, 2002b, p. 101).

As quatro regras são observadas por quem pretende ser apreendido pelo leitor como um autor de atos ilocutórios sérios, ou assertivos. No exemplo analisado em "O estatuto lógico do discurso ficcional", Searle recorre a um trecho de notícia de jornal para ilustrar a postura de quem se compromete a comprovar a natureza verdadeira, como comprovável empiricamente, do ato ilocutório. As convenções verticais são regras. Ao recorrer à notícia, Searle facilita sua demonstração, pois as convenções referem-se ao gênero que configura o texto, o que faz com que elas sejam anteriores à leitura, ocorrendo já no âmbito paratextual. O compromisso com a verdade e com a disposição de indícios ou razões que a comprovem é uma convenção atrelada ao gênero e não à sua constituição linguística. Por isso, Searle admite que a mesma narrativa contida na notícia poderia constar de uma obra ficcional e ser apreendida como fingimento. Falta a Searle o reconhecimento de que a natureza genérica precede à sua leitura e estabelece o contrato antes de sua apreensão como constituída por asserções, sejam genuínas ou fingidas. O gênero, em si, é assertivo, sério, antes que a verdade de suas asserções seja considerada crível.

Para a ficção, Searle estabelece o que chama de "convenções horizontais", algo que se resume, a rigor, apenas à suspensão da natureza de regra das convenções verticais. Ou seja:

Ora, o que torna possível a ficção, segundo sugiro, é um conjunto de convenções extralinguísticas, não semânticas, que rompem a ligação entre as palavras e o mundo estabelecida pelas regras atrás mencionadas. Pensemos nas convenções do discurso ficcional como um conjunto de convenções horizontais que rompem as ligações estabelecidas pelas regras verticais. Suspendem as exigências normais estabelecidas por estas regras. Tais convenções horizontais não são regras de significado; não fazem parte da competência semântica do falante. Consequentemente, não alteram ou 
modificam os significados das palavras ou outros elementos da língua. O que fazem é antes permitir ao falante usar as palavras com os seus significados literais sem assumir os compromissos que esses significados normalmente exigem. (SEARLE, 2002b, p. 104)

Esse rompimento com as convenções verticais é uma postura ilocutória que, para ser reconhecida pelo leitor, precisa de elementos que a identifiquem como tal. $\mathrm{O}$ texto, mesmo sendo composto pela linguagem, não dispõe de recursos linguísticos que possam identificá-la. $\mathrm{Ou}$, pelo menos, de recursos linguísticos que possam ser aplicados aos atos de fala em separado, como asserções isoladas. Assim, torna-se necessário distinguir o momento em que essa relação contratual se estabelece e evidencia que as convenções verticais foram suspensas. Algo que, em Searle, repousa sobre as asserções em separado, o que faz com que um comentário de Tolstoi possa ser entendido como sério, não sendo parte do ficcional, mesmo inserido em um romance.

A possibilidade de, no interior de um romance, uma asserção poder ser reconhecida como genuína, ou séria, correspondendo ao que o autor considera como verdade, é problemática em Searle. Em princípio, ela dependeria do conhecimento acerca do real de que o leitor dispusesse. É o que fica evidenciado através dos exemplos a que Searle recorre. São, em sua maioria, referências a lugares ou a fatos históricos. Os lugares de Londres, com suas devidas descrições, em romances de Arthur Conan Doyle, não seriam asserções ficcionais ou fingidas. Assim como os fatos históricos contidos em romances como Guerra e paz. Fatos reconhecíveis e checáveis a partir das convenções verticais. No entanto, a verdade de asserções como comentários ou juízos morais não tem sua comprovação assegurada senão pelo reconhecimento da personalidade do autor. Ela dependeria mais da intuição do receptor do que de uma relação contratual que estivesse sinalizada e demarcada no texto. Ou aquele teria que dispor de informações acerca do autor.

Por isso, a posição de Searle a respeito da possibilidade de graus de rompimento com as convenções verticais pode explicar fenômenos diretamente relacionados a subgêneros ou a estéticas:

O autor estabelecerá com o leitor um conjunto de entendimentos sobre até que ponto as convenções horizontais da ficção rompem as conexões verticais do discurso sério. Na medida em que o autor for consistente com as convenções que invocou ou (no caso de formas revolucionárias de literatura) as convenções que estabeleceu, permanecerá dentro das convenções. No que respeita à possibilidade da ontologia, tudo vale: o autor pode criar qualquer personagem ou acontecimento que queira. No que respeita à aceitabilidade da ontologia, a coerência é uma consideração crucial. 
Contudo, não há critério universal da coerência: o que conta como coerência numa obra de ficção científica não contará como coerência numa obra naturalista. O que conta como coerência será em parte uma função do contrato entre o autor e o leitor acerca das convenções horizontais. (SEARLE, 2002b, p. 107).

A ideia de contrato soa estranha no trecho acima, pois ele não depende de uma ação ocorrida de uma vez e que valha para toda a duração da leitura. Não haveria um momento em que o rompimento com as regras ocorresse, e elas permanecem latentes ao longo da leitura de obra ficcional. Uma obra será reconhecida como naturalista ao longo de sua leitura, a não ser que elementos paratextuais ou extraliterários tenham informado o leitor sobre isso, o que, evidentemente, não constitui um contrato firmado pelo autor no interior do texto.

Searle não atenta para um reconhecimento paratextual do gênero. O contrato pode servir para se explicarem fenômenos narrativos como a ficção autobiográfica e, sobretudo, a autoficção, desde que o reconhecimento da natureza autobiográfica ou da ficcional fosse disposto como ocorrendo em momentos diferentes do estabelecimento da relação contratual, ou do pacto de leitura. O que Lejeune considera como pacto autobiográfico ou romanesco ocorre quando se reconhecem, de antemão, os gêneros a partir dos quais as obras devem ser apreendidas. Apenas quando fala em pacto fantasmático, que seria o da ficção autobiográfica, Lejeune adentra o problema de um tipo de contrato de leitura depender do conteúdo inserido no texto e não de convenções paratextuais. Ou seja, a noção de contrato ou pacto de leitura depende de elementos que começam no reconhecimento do gênero, mas que só se desvelam como sedimentação ou inovação durante a leitura.

\section{A RELAÇÃO ENTRE AUTOBIOGRAFIA E FICÇÃO COMO PACTO DE LEITURA AMBÍGUO PORQUE DURATIVO}

As concepções de pacto de leitura elaboradas por teóricos da literatura, como Philippe Lejeune e Wolfgang Iser, encontram um elemento problematizador quando observadas a partir da concepção de um linguista como John R. Searle. A natureza mais abrangente da Linguística faz com que os estudos da Teoria Literária tenham que atentar para ela, pois arte é linguagem.

Searle é certeiro ao enxergar a existência de contratos de leitura como tendo prioridade sobre a configuração linguística para que se possa definir a natureza do texto. Sua atenção recai sobre a ficcionalidade ou verdade dos textos narrativos que aborda. As suas convenções verticais são as mesmas que orientam Lejeune ao definir as condições do pacto 
autobiográfico: o compromisso com o leitor de se poder confirmar a verdade dos fatos narrados. Lejeune também suspende a exigência dessa comprovação ao falar do pacto romanesco e enxerga no pacto fantasmático também essa suspensão: o reconhecimento do elemento autobiográfico altera o pacto de leitura, mas isso não é uma exigência da obra. Estamos no âmbito da prefiguração, de Ricoeur. A possibilidade de o leitor perceber o elemento memorialístico, até mesmo autobiográfico, existe e altera o modo de leitura. Mas é algo reservado ao leitor-ideal.

Essa percepção depende de uma duração constituída pelo tempo da leitura. Como arte do tempo, a literatura pressupõe uma duração para sua recepção pelo leitor. Iser foi preciso ao reconhecer essa duração. O primeiro plano de leitura é o reconhecimento do gênero e então entra em ação o repertório de leituras do leitor. Existe a tradição literária. Ou seja, a sedimentação que filia a obra a um gênero. O segundo plano de leitura é o do reconhecimento de como cada obra se relaciona com a tradição sedimentada, e então o leitor-ideal é aquele que dispõe de conhecimentos sobre técnicas literárias que o habilitam a reconhecer a inovação, o modo como cada obra pode ser original e contribuir para a evolução do gênero. Existe, de fato, um contrato de leitura que principia no paratexto. O leitor reconhece o gênero e cria as expectativas para a leitura. No entanto, é a duração desta que desvela a natureza única da obra lida. Por isso, a obra é jogo e cada leitura é uma partida. As regras de jogo, evidentemente, são construídas desde o paratexto, mas vão ganhando complexidade ao longo da leitura. O leitor de Tristram Shandy, de Sterne, reconhece o romance como pertencendo a esse gênero para, em seguida, reconhecê-lo como romance-autobiográfico, no sentido de Bakhtin (2015) de assimilação do formato da autobiografia; há um pacto de leitura que é ficcional. No entanto, as inovações que Sterne constrói a todo instante vão sendo apreendidas na duração da leitura, como o fato de o protagonista ter nascido quase na metade da extensa narrativa, e de ela não narrar uma autobiografia que mimetiza o gênero dentro do romance. A assimilação das regras de jogo depende, portanto, dessa duração e não cessa antes de a narrativa acabar. Os dois planos de Iser ficam evidentes. Assim como a natureza de assimilação de gêneros pelo romance, de que fala Bakhtin (2015, p. 108): "Em princípio, qualquer gênero pode ser incluído na construção do romance, e de fato é muito difícil encontrar em gênero que não tenha sido introduzido algum dia e por alguém no romance", mesmo o teórico tendo afirmado a predileção do gênero romance por certos gêneros, sempre recorrentes nele: 
São eles: a confissão, o diário, a descrição de viagens, a biografia, a carta e alguns outros gêneros. Todos esses gêneros podem não só integrar o romance como sua construção essencial, mas também definir a forma do romance como um todo (romance-confissão, romance-diário, romance em cartas, etc.). Cada um desses gêneros tem suas formas verbo-semânticas de assimilação de diversos aspectos da realidade. (...) Todos esses gêneros que integram o romance inserem nele as suas linguagens e por isso estratificam a sua unidade linguística e, a seu modo, aprofundam a sua natureza heterodiscursiva. (BAKHTIN, 2015, p. 108-109)

Outro exemplo: em Esaú e Jacó, Machado de Assis principia o romance por um falso prólogo em que evidencia o foco narrativo a ser usado: um narrador-testemunha escreveu o que vivenciou na casa de conhecidos. O contrato ficcional finge não sê-lo; no entanto, fica cada vez mais intenso conforme o narrador-testemunha transgride as convenções narrativas reconhecidas para esse foco: o narrador machadiano conhece os processos internos de seus protagonistas e chega a narrar cenas de suas intimidades. Machado estabelece regras de jogo conforme a narrativa evolui. Se essas regras são pactuais, conforme Iser define, elas têm no paratexto e no falso prólogo apenas um começo. A inovação é percebida na duração da leitura. Algo que Bakhtin não aponta, ao fazer da mimetização de gêneros, no romance, uma imitação e não um desdobramento.

Searle poderia ter dito, acerca de Tristram Shandy, que as páginas metaficcionais, em que o narrador discute a própria construção da narrativa, são asserções legítimas; assim como poderia ter dito que os fatos históricos acerca da proclamação da república, em Esaú e Jacó, também o são. O problema em Searle é que ele não admitiria um contrato a partir do paratexto e de elementos como o reconhecimento do subgênero. $O$ fato de ele enxergar cada asserção como séria ou fingida transformaria o reconhecimento das regras de jogo, sobretudo a relação entre sedimentação e inovação, em uma configuração estética simples demais para a complexidade de obras como as exemplificadas acima. As asserções sérias de Sterne e de Machado estão ali exatamente para que o leitor possa rir a partir delas e ver o caráter não sério, transgressor, dessas verdades dentro dos subgêneros em que se inserem.

Nos casos da ficção autobiográfica e da autoficção, a oscilação binária proposta por Searle entre ficção e verdade, entre fantasia e fato real, acaba por ser útil para a compreensão dos processos de leitura dessas modalidades narrativas. Quando Lejeune propõe a existência dessa mistura de naturezas, na ficção autobiográfica, ele sugere que o leitor possa estar de posse da informação autobiográfica e atrelá-la, como verdade, ao autor. Um pacto confuso, mas não essencial a quem começou a ler uma obra como ficcional. Na ficção autobiográfica já haveria fatos autobiográficos, que poderiam ser confirmados através de informações sobre o 
autor. No entanto, quando Doubrovsky cria o conceito de autoficção, ele evidencia que o sucesso da leitura depende dessa oscilação entre invenção ficcional e fato autobiográfico e que o texto não deve precisar seus limites. É condição essencial do pacto de leitura da autoficção a imprecisão das naturezas ficcional ou autobiográfica da narrativa. Mas Doubrovsky, assim como Searle, enxerga na leitura a constituição desse pacto, que Alberca chamaria depois de "ambíguo". Trata-se de uma ação durativa. Doubrovsky não dá a devida atenção ao elemento paratextual, que possibilita que uma obra, como seu Fils, possa ser começada como romance, para que durante a leitura os elementos autobiográficos possam ser detectados pelo leitor. A atenção para o extraliterário, como os dados biográficos, é provocada por uma identidade onomástica que desperta o interesse pela comprovação do teor autobiográfico. Aí, sim, para ele, ocorreria uma impossibilidade de reconhecimento da natureza e do gênero da obra. $\mathrm{O}$ seu pacto dependeria da duração da leitura e não chegaria a uma conclusão sobre a natureza ficcional ou autobiográfica do texto, gerando uma nova modalidade de narrativa. A mistura das duas faria da obra uma autoficção.

Doubrovsky já aventava a possibilidade de um reconhecimento da natureza autobiográfica através da coincidência de nomes entre autor, narrador e protagonista. Tantas obras autoficcionais assumiram essa coincidência, como Divórcio, de Ricardo Lísias, e Diário da queda, de Michel Laub. No entanto, o desdobramento dessa modalidade narrativa preferiu a ambiguidade do pacto a essa coincidência de nomes. O que torna possível que se olhem para contos como "Prelúdio", "Na baía" e "A casa de bonecas", de Katherine Mansfield, ou para narrativas maiores, como Água viva, de Clarice Lispector, ou O filho eterno, de Cristóvão Tezza, como exemplos de autoficcionalidade em que os textos evidenciam sua natureza autobiográfica através de pistas, índices que o leitor proficiente, sobretudo o leitor-ideal, detecta. Neles, os lugares são elementos essenciais. Em seguida, nomes ficcionais mas que conservam traços que os assemelham aos nomes reais. E, finalmente, biografemas que são do conhecimento daquele leitor-ideal que conhece as biografias e as personalidades dos autores que leem com atenção. Hábitos, gostos, episódios da infância. No passado, era mais difícil para um autor tornar-se reconhecido como personagem. Katherine Mansfield mantinha um diário, publicado pouco depois de sua morte, em que ela trata da memória, do autobiográfico, como elemento que prefigura seus contos. Da mesma forma, mantinha uma correspondência com amigos e intelectuais que constituiriam uma reserva de leitores-ideais. No caso de Clarice Lispector, a autora dispunha de sua condição de cronista de diversos jornais, ao longo de anos, para mostrar ao leitor sua personalidade, discutir sobre o processo de escrituração de obras e tratar de fatos autobiográficos. Trata-se de um modelo daquilo que Diana Klinger 
chama de performance, ou seja, a "dramatização de si que supõe, da mesma maneira que ocorre no palco teatral, um sujeito duplo, ao mesmo tempo real e fictício, pessoa (ator) e personagem" (KLINGER, 2012, p. 49. Grifos da autora), mais rápida e de maior alcance que a atitude de Mansfield, porém menos ágil e profícua que a de autores como Ricardo Lísias e Domingos Pellegrini, que escrevem sobre si em colunas de jornal, blogs e páginas pessoais. $\mathrm{O}$ mesmo pode ser dito de autores como Patrick Modiano e J. M. Coetzee, que fazem de conferências e entrevistas formas eficientes de performance.

Trata-se, sem dúvida, de uma forma de garantir que o contrato ambíguo da autoficção tenha como dispor de uma ancoragem na natureza autobiográfica, mesmo para aqueles leitores que não chegam ao ideal. É uma forma de se garantir que a natureza do pacto da autoficção não se torne causa de fracasso da leitura. Da mesma forma, os autores podem adentrar mais no âmbito da própria intimidade, sem o risco de não serem reconhecidos como matéria para obras ficcionais. Confirmam o que Ricoeur via como prefiguração.

E, aqui, novamente, volta-se ao princípio da discussão: ser obra ficcional é uma condição basilar para a existência da autoficção. Por isso, a definição de Searle da ficção como efeito de contrato de leitura ajuda tanto a se entenderem os mecanismos pelos quais o pacto ambíguo se efetiva. Faltava a Searle uma atenção maior para as convenções que fazem com que os gêneros narrativos como o romance, o conto, a novela e a crônica possam ser apreendidos, já no paratexto, como obras de ficção. Mesmo que aquilo que narram seja fato real. Assim como a percepção de que um gênero como a autobiografia canônica quer ser vista como narrativa de fatos reais, mesmo que um teórico como Paul de Man afirme que ela não passa de criação do imaginário. As categorizações de gênero possibilitam que, por mais que as obras oscilem dentro da aceitação ou da negação das convenções verticais ou horizontais de Searle, elas já sejam recebidas, de antemão, como ficcionais ou autobiográficas, asserções fingidas ou genuínas. Trata-se daquele primeiro plano de leitura, de que trata Iser, que depende do repertório do leitor. A condição de cada obra como mais evidentemente ficcional ou mais evidentemente autobiográfica faz parte daquele segundo plano de leitura, que depende da habilidade de reconhecer procedimentos artísticos. Nele, existe o espaço para a inovação, como a que significou a categorização da autoficção como modalidade narrativa, a partir da década de 1970.

O primeiro plano é mais estático, exige que se olhe para a tradição, para gêneros sedimentados. Da mesma forma, olha-se para o paratexto. É o momento em que, juntamente com as informações provenientes do repertório de leituras, ganham destaque as informações obtidas graças às performances diversas, que podem ir de diários íntimos, não autorizados, até 
as redes sociais dos autores, passando-se pelos verbetes, pelas biografias, pelas entrevistas e conferências, entre outras formas de exposição do eu. A posse de tais informações complementa a definição do gênero, convencionado como ficcional. Tais informações também podem ser adquiridas durante a duração da leitura.

O segundo plano é o do reconhecimento das especificidades da obra que se lê. As regras de jogo de leitura, que cada obra especifica como pacto, partem daquela já definida no primeiro plano de leitura para as suplantar. A inovação ou até mesmo o estilo pessoal de se tratar o gênero sedimentado constituem a experiência mais complexa da leitura. É através dela, do estranhamento gerado, que a leitura ganha profundidade e pode ser uma partida única daquele jogo. É um processo que depende da duração e dialoga com a intencionalidade do autor.

Uma ação durativa, conforme o jogo de ambivalência que Searle havia estabelecido. O que nele era a percepção de asserções como ficcionais ou sérias torna-se, na autoficção, o reconhecimento da natureza de trechos como ficcionais ou autobiográficos, ou até mesmo da impossibilidade de estes serem definidos pelo leitor. Na autoficção, a natureza ficcional é dada pelo gênero. A natureza autobiográfica, pela atenção para os biografemas detectáveis ao longo do texto. No sentido iseriano, essas percepções do leitor são temas que ele observa, e que formam uma sequência. Essa sequência, no caso da autoficção, permanece imprecisa após a leitura.

No entanto, é preciso que se entenda que, ao contrário da ambivalência de Searle, é imprescindível que a autoficção seja entendida como algo indissolúvel, um resultado estético em que não se separam asserções em sequência. A complexidade da autoficção é uma derivação da relação entre prefiguração, configuração e refiguração, de Ricoeur, em que tais elementos não são escondidos do leitor, mas se misturam ao imaginário, de Iser, à memória fantástica, de Platão, de modo a fazer da imprecisão uma possibilidade de desdobramentos de sentidos e de inovações técnicas, como a criação de focos narrativos que mimetizam gêneros performáticos, como a entrevista, a confissão, o diário. Os tais graus de aceitação ou cancelamento das convenções de Searle são percebidos no tempo da leitura. Partem do gênero, como paratexto, mas precisam do extraliterário, da informação sobre os biografemas. Por isso, a autoficção jamais seria um gênero literário, assim como a ficção não o é. 


\section{CONSIDERAÇÕES FINAIS}

A concepção de pacto de leitura, ou de contrato, tornou-se essencial não apenas para se tentar demonstrar os modos como as obras literárias são apreendidas, mas também para que se especifiquem seus processos constitutivos. Ou seja, a refiguração acaba por explicitar os modos de configuração da obra de arte literária, assim como sua origem na memória do autor, seja isto evidenciado, sugerido ou até mesmo negado.

No caso específico da autoficção e até da ficção autobiográfica, a memória como origem da elaboração de gênero ficcional pode se desnudar ou estar disponível para um pequeno número de leitores. No entanto, o desnudamento da memória, como autobiografia, que ocorre na autoficção, destaca-se por preservar a imprecisão de seus limites. Não aquela imprecisão de que tratava Paul de Man, assim como não é a de Paul Ricoeur. A imprecisão da autoficção é perseguida como elemento constitutivo da sua natureza: ser ficção, por partir de formas sedimentadas pelos gêneros ficcionais, sobretudo o romance, e ser autobiografia, naquele sentido de escrita sobre si mesmo dado por Lejeune.

Definida como prática que faz uso do pacto de leitura ambíguo, ela pode ser focalizada a partir de inúmeras concepções de pacto ou de contrato de leitura. É mistura de pacto autobiográfico e romanesco, se usarmos termos de Lejeune. Precisa que os limites entre tais pactos permaneçam imprecisos, conforme Doubrovsky. O pacto que a define é o ambíguo, conforme Alberca, mais que qualquer coincidência de nomes.

Antes disso, Iser já havia definido a literatura como um jogo, em que o pacto reside na aceitação das regras que cada obra propõe. A autoficção determina suas regras, se seguirmos Iser, a partir do reconhecimento dos gêneros ficcionais que assume, para em seguida inovar e transgredir. Por isso, ela mimetiza os discursos dos gêneros literários ficcionais, assim como os das escritas-de-si, para que se retome aqui Bakhtin. Essa mistura de gênero ficcional com escrita-de-si é um dos recursos de configuração que asseguram a sua ambiguidade.

Em Searle, ficção ou verdade são relações contratuais de leitura, que dependem de convenções. Existe uma escala que vai da completa adesão à completa negação dessas convenções, o que poderia colocar ficção e verdade em lados opostos, mas elas se imbricam e se misturam, ali onde a maneira de assumirem-se as convenções oscilam. Ler um texto como ficção ou verdade é escolha que depende do reconhecimento da intenção de quem o produziu. Uma relação contratual, pacto de leitura, mas que em Searle não enxerga uma obra como unidade, mas como sequência de asserções legítimas ou ficcionais. 
Essa sequência, como alternância, pode ajudar a explicar como um leitor de autoficção lê a mesma obra como ficção e como autobiografia. Mas esbarra na ideia de unidade, de que a obra de arte necessita para ter uma configuração bem sucedida e uma recepção satisfatória, como leitura. Por isso, essa alternância de Searle precisa ser vista como parte do que, em Iser, é o segundo plano da leitura, o de reconhecimento de especificidades da obra, de suas regras próprias, após a focalização como parte de uma tradição que a insere em um gênero literário. Enxergar trechos como invenção e outros como autobiografia é fazer deles temas que formam a unidade final da obra. A relação entre a forma sedimentada e a inovação permite que se entenda a autoficção, e até mesmo a ficção autobiográfica, como modos originais de se fazer da memória a base para a configuração artística. Perceber essas possibilidades de configuração é algo que se espera do leitor-ideal da autoficção, aquele que reconhece a autobiografia no gênero ficcional e dispõe de repertório de leituras para isso.

\section{REFERÊNCIAS}

ALBERCA, Manuel. El pacto ambiguo: de la novela autobiográfica a la autoficción. Madrid: Biblioteca Nueva, 2007.

BAKHTIN, Mikhail. Teoria do romance I: a estilística. Tradução de Paulo Bezerra. São Paulo: Editora 34, 2015.

COMPAGNON, Antoine. O demônio da teoria: literatura e senso comum. Tradução de Cleonice Paes Barreto Mourão e Consuelo Fortes Santiago. $2^{\mathrm{a}}$ ed., Belo Horizonte: Editora UFMG, 2010.

DOUBROVSKY, Serge. O último eu. In: NORONHA, Jovita Maria Gerheim (org.). Ensaios sobre a autoficção. Tradução de Jovita Maria Gerheim Noronha e Maria Inês Coimbra Guedes. Belo Horizonte: Editora UFMG, 2014.

ISER, Wolfgang. O ato de leitura: uma teoria do efeito estético. Vol. 1. Tradução de Johannes Kretschmer. São Paulo: Editora 34, 1996.

KLINGER, Diana. Escritas de si, escritas do outro: o retorno do autor e a virada etnográfica. Rio de Janeiro: 7Letras, 2012.

LEFEBVE, Maurice-Jean. Estrutura do discurso da poesia e da narrativa. Tradução de José Carlos Seabra Pereira. Coimbra (Portugal): Livraria Almedina, 1980.

LEJEUNE, Philippe. O pacto autobiográfico: de Rousseau à Internet. Organização de Jovita Maria G. Noronha. Trad. Jovita Maria G. Noronha e Maria Inês Coimbra Guedes. Belo Horizonte: Editora UFMG, 2008.

MAN, Paul de. The rhetoric of Romanticism. New York: Columbia University Press, 
1994.

RICOEUR, Paul. Tempo e narrativa. Tradução de Cláudia Berliner e Márcia Valéria Martinez de Aguiar. São Paulo: WMF Martins Fontes, 2010.

SEARLE, John R. Intencionalidade. Tradução de Júlio Fischer e Tomás Rosa Bueno. $2^{\mathrm{a}}$ ed., São Paulo: Martins Fontes, 2002a.

O estatuto lógico do discurso ficcional. In: SEARLE, John R. Expressão e significado: estudos da teoria dos atos de fala. Tradução de Ana Cecília G. A. de Camargo e Ana Luíza Marcondes Garcia. 2a ed., São Paulo: Martins Fontes, $2002 b$.

Recebido: $17 / 09 / 2020$

Aprovado: 20/01/2021 